\title{
PENGARUH DANA BERGULIR KEMENTERIAN KOPERASI DAN UKM LPDB-KUMKM TERHADAP PENGEMBANGAN USAHAKOPERASI SIMPAN PINJAM AGRIBISNIS DI KABUPATEN MAJALENGKA
}

\author{
Yon Giri Mulyono, Ratna Verawati, Achmad Tjachja Nugraha
}

\begin{abstract}
ABSTRAK
Tujuan penelitian ini adalah: (1) mengetahui proses penyaluran dana bergulir bagi koperasi simpan pinjam agribisnis, (2) mengetahui besar persentase pengembangan aset, pinjaman/pembiayaan, modal sendiri, SHU, dan tenaga kerja koperasi simpan pinjam agribisnis di Kabupaten Majalengka antara antara sebelum menerima dana bergulir dengan sesudah menerima dana bergulir pada tahun pertama dan tahun kedua, (3) mengetahui pengaruh dana bergulir terhadap pengembangan aset, pinjaman/pembiayaan, modal sendiri, SHU dan tenaga kerja koperasi simpan pinjam agribisnis di Kabupaten Majalengka antara sebelum menerima dana bergulir dengan sesudah menerima dana bergulir pada tahun pertama dan tahun kedua. Hasil penelitian menunjukan penyaluran dana bergulir LPDB-KUMKM bagi Koperasi simpan pinjam dilakukan dengan sistem executing dimana koperasi simpan pinjam mempunyai tanggung jawab menyeleksi dan menetapkan penerima dana bergulir, menyalurkan dan menagih kembali dana bergulir, serta menanggung risiko terhadap ketidaktertagihan dana bergulir. Berdasarkan penghitungan menggunakan rumus presentase pengembangan usaha diperoleh peningkatan nilai aset setelah menerima dana bergulir pada tahun pertama (2010) sebesar 28.06\% dan pada tahun kedua (2011) sebesar 55.99\%. Peningkatan nilai pinjaman/pembiayaan setelah menerima dana bergulir pada tahun pertama (2010) sebesar 26.07\% dan pada tahun kedua (2011) sebesar 54.94\%. Peningkatan nilai modal sendiri setelah menerima dana bergulir pada tahun pertama (2010) sebesar $13.33 \%$ dan pada tahun kedua (2011) sebesar67.24\%. Peningkatan SHU setelah menerima dana bergulir pada tahun pertama (2010) sebesar $27.61 \%$ sedangkan pada tahun kedua mengalami penurunan sebesar -27.61\%. Peningkatan jumlah tenaga kerja setelah menerima dana bergulir pada tahun pertama (2010) sebesar $29.41 \%$ dan pada tahun kedua (2011) sebesar $48.53 \%$.
\end{abstract}

Kata Kunci : Revolving funds, cooperatives, micro-enterprises, savings and loans, productive businesses 


\begin{abstract}
The purpose of this study are: (1) understand the process of revolving funds for savings and credit cooperatives agribusiness, (2) determine the percentage of development assets, loans / financing, equity capital, SHU, and labor savings and loans cooperatives agribusiness in Majalengka between the prior receiving revolving funds with after receiving a revolving fund in the first year and second year, (3) the effect of a revolving fund for the development of assets, loans / financing, equity capital, SHU and labor savings and loans cooperatives agribusiness in Majalengka between before receiving revolving funds with after receiving a revolving fund in the first year and second year. The results showed revolving funds LPDB-KUMKM for cooperative savings and loan is done by executing a system where credit unions have a responsibility to select and establish a revolving fund recipients, distribute and charge back the revolving fund, as well as the risk to ketidaktertagihan revolving fund. Based on the calculation using the formula percentage of business development gained increased value of assets after receiving a revolving fund in the first year (2010) amounted to $28.6 \%$ and in the second year (2011) amounted to $55.99 \%$. Increasing the value of the loan / financing after receiving a revolving fund in the first year (2010) amounted to $26.07 \%$ and in the second year (2011) amounted to $54.94 \%$. The increase in the value of equity capital after receiving a revolving fund in the first year (2010) at 13:33\% and in the second year (2011) sebesar67.24\%. Increased SHU after receiving a revolving fund in the first year (2010) amounted to $27.61 \%$, while in the second year decreased by $-27.61 \%$. Increasing the number of workers after receiving a revolving fund in the first year (2010) amounted to $29.41 \%$ and in the second year (2011) amounted to $48.53 \%$.
\end{abstract}

Keywords: Revolving funds, Cooperatives, micro-enterprises, savings and loans, productive businesses

\section{PENDAHULUAN}

\section{Latar Belakang}

Koperasi sering disebut sebagai pilar gerakan ekonomi rakyat. Koperasi juga menjadi kunci pengentas kemiskinan dan penyedia lapangan kerja. Kontribusi koperasi untuk Produk Domestik Brutto (PDB) Indonesia adalah 56,2\% pada tahun 2009. Angka ini mengalami peningkatan sebesar $50 \%$ dari tahun
2008. Dengan peningkatan jumlah koperasi yang telah mencapai 170.411 unit hingga Desember 2009, eksistensi gerakan perekonomian rakyat tersebut makin meningkat sehingga mendorong perekonomian Indonesia. ("Koperasi Sumbang PDB 56,2\%”, Batavia.co.id, 12 Juli 2010).

Bagi Indonesia yang baru saja ditimpa krisis dalam berbagai sendi kehidupan dari sosial budaya, politik, dan 
ekonomi dalam menghadapi globalisasi merupakan tantangan yang terasa amat berat. Hambatan yang terjadi adalah kurang siapnya mental masyarakat dalam menghadapi era ini. Oleh karena itu dibutuhkan peran lembaga yang berbasis rakyat yang menopang kegiatan ekonomia rakyat jadi satu kesatuan yang saling membantu dalam mendorong perekonomian Indonesia yaitu koperasi.

Prospek pengembangan koperasi sangat terkait dengan peningkatan kebutuhan masyarakat terhadap kelembagaan ekonomi yang memiliki ciri seperti koperasi. Faktor-faktor pendorong peningkatan kebutuhan tersebut adalah adanya pertumbuhan dan perkembangan ekonomi yang tidak lagi dapat diakomodasi oleh kegiatan ekonomi individual yang berskala kecil dengan berbagai keterbatasan. Misalnya para petani dan pedagang yang telah mampu meningkatkan produktivitasnya membutuhkan kelembagaan yang menunjang pelayanan usaha yang berbasis rakyat. (Ibnoe Soedjono et.al, 2000 h.3940)

Peran koperasi simpan pinjam dalam menunjang agribisnis berbasis rakyat akan lebih optimal bila ditunjang dengan sistem perencanaan yang terpadu, berkelanjutan dan ditopang dengan anggaran yang memadai. Untuk memperkuat posisi koperasi maka ketersediaan modal bagi pelaku usaha koperasi simpan pinjam merupakan sebuah keharusan.

Keterbatasan modal yang dimiliki koperasi simpan pinjam agribisnis merupakan hambatan struktural untuk mengembangkan usaha koperasi. Sehingga koperasi belum memiliki kemampuan untuk menjalankan peranannya secara efektif. Kelangkaan modal pada koperasi simpan pinjam agribisnis menjadi faktor yang menyebabkan lemahnya perkoperasian di Indonesia selama ini. (Pandji dan Ninik, 2007 h. 127)

Keberhasilan koperasi memang sangat ditentukan oleh peran pemerintah. Pada awal kemunculan koperasi pun memang dilakukan oleh dorongan pemerintah, bahkan sejak pemerintahan penjajahan Belanda telah mulai diperkenalkan. Secara khusus pemerintah memerankan fungsi regulatory dan development secara sekaligus (Shankar, 2002). Pemerintah menetapkan tiga pola pengembangan koperasi di Indonesia. Ciri utama perkembangan koperasi di Indonesia adalah dengan pola penitipan kepada program yaitu : (1) Program pembangunan secara sektoral seperti koperasi pertanian, koperasi desa, KUD, (2) Lembaga-lembaga pemerintah dalam koperasi pegawai negeri dan koperasi fungsional lainnya, dan (3) Perusahaan baik milik negara maupun swasta dalam koperasi karyawan. (Noer, Jurnal Kementrian Koperasi Dan UKM)

Peran pemerintah sebagai development koperasi simpan pinjam agribisnis ditunjukan dengan kebijakan PJP I (Pembangunan Jangka Panjang-I). Pada PJP I pemerintah membentuk KUD (Koperasi Unit Desa) dikembangkan untuk menunjang program swasembada beras dalam meningkatkan perekonomian di 
sektor pertanian. Program ini ditunjang pemerintah dengan pemberian subsisi seperti KUR (Kredit Usaha Rakyat) dan dana bergulir (Noer, Jurnal Kementrian Koperasi Dan UKM)

Sejak Tahun 2006 pemerintah melalui Kementrian Koperasi dan Usaha Mikro Kecil Menengah membentuk Lembaga Pengelola Dana Bergulir Koperasi dan Usaha Mikro, Kecil dan Menengah (LPDB-KUMKM). LPDBKUMKM bertugas memberikan pinjaman dana bergulir bagi koperasi simpan pinjam guna memperkuat usaha koperasi simpan pinjam.

Berdasarkan data Badan Pusat Statistik (BPS) jumlah penduduk di Indonesia tahun 2009 mencapai 237.641.326 jiwa. Jumlah usaha mikro kecil menengah mencapai 17.145.244 unit dengan perkembangan sektor agribisnis mencapai 5.5\% hingga 6\%. Data LPDBKUMKM sampai tahun 2011 menyebutkan jumlah penerima dana bergulir di seluruh Indonesia mencapai 983 koperasi. Kabupaten Majalengka merupakan salah satu wilayah yang menerima dana bergulir Kementrian Koperasi dan UKM LPDBKUMKM.

Perkembangan koperasi di Kabupaten Majalengka dengan jumlah koperasi sebanyak 631 koperasi, koperasi yang masih aktif sebanyak 292 koperasi dan koperasi yang tidak aktif sebanyak 339 koperasi. Jumlah koperasi yang telah melaksanakan RAT sebanyak 169 koperasi atau 27\% ("Banyak Koperasi Sudah Tidak Aktif”, Suara Majalengka Online, 18 Agustus 2011)
Penyaluran dana bergulir Kementrian Koperasi dan UKM ditujukan untuk meningkatkan pengembangan usaha koperasi simpan pinjam di Kabupaten Majalengka sehingga koperasi diharapkan mampu meningkatkan usaha agribisnis rakyat dalam upaya meningkatkan pemasukan asli daerah. Hal ini karena agribisnis penyumbang terbesar Produk Domestik Regional Bruto (PDRB) Kabupaten Majalengka tahun 2005 sebesar $30,08 \%$ dari sektor agribisnis, terdiri dari pertanian, perkebunan, peternakan, perikanan, dan kehutanan (Situs Pemerintah Kabupaten Majalengka).

\section{METODE PENELITIAN}

\section{Lokasi dan Waktu Penelitian}

Penelitian ini dilaksanakan di Lembaga Pengelola Dana Bergulir Koperasi dan Usaha Mikro Kecil Menengah (LPDB-KUMKM) Kementerian Koperasi dan Usaha Kecil Menengah, jl. Letjend. MT. Haryono Kav. 52-53 Jakarta dan Koperasi Simpan Pinjam Agribisnis di Kabupaten Majalengka. Waktu pelaksanaan penelitian dilakukan pada November 2011 sampai Februari 2012. Lokasi ini dipilih dengan pertimbangan bahwasannya LPDB-KUMKM tersebut menyalurkan pinjaman dana bergulir dan koperasi simpan pinjam agribisnis di Kabupaten Majalengka merupakan penerima dana bergulir.

\section{Jenis Dan Sumber Data}


Data yang digunakan dalam penelitian ini terdiri dari 2 jenis, yaitu data primer dan data sekunder. Data primer merupakan jenis data yang diperoleh dan digali dari sumber asli baik berupa data kualitatif maupun data kuantitatif, sedangkan data sekunder adalah jenis data yang diperoleh dan digali melalui hasil pengolahan pihak kedua dari hasil penelitian lapangannya baik berupa data kualitatif maupun kuantitatif (Muhammad Teguh, 2005: 122). Data primer digunakan untuk menjawab permasalahan utama yang diangkat dalam penelitian, sedangkan data sekunder digunakan sebagai bahan informasi penunjang dalam melakukan analisis.

\section{Metode Pengambilan Data}

Data dalam penelitian ini dikumpulkan melalui 3 metode, yaitu metode observasi, wawancara, dan studi dokumentasi. Berikut penjelasan metode pengumpulan data yang digunakan dalam penelitian.

\section{Observasi}

Observasi merupakan salah satu teknik operasional pengumpulan data melalui proses pencatatan secara cermat dan sistematis terhadap objek yang diamati secara langsung. Metode observasi yang dilakukan adalah obervasi tanpa partisipasi (observasi non-participant) yaitu melakukan pengamatan seperlunya (Muhammad Teguh, 2005: 134). Dalam penelitian ini observasi dilakukan untuk mengetahui penyaluran dana bergulir di LPDB-KUMKM dan pengelolaan dana bergulir oleh Koperasi simpan pinjam Agribisnis di Kabupaten Majalengka.

2. Wawancara

Wawancara merupakan metode pengumpulan data dengan cara bertanya langsung antara pihak peneliti dan responden (Muhammad Teguh, 2005:

136). Dalam penelitian ini wawancara dilakukan dengan staf Bidang Pengkajian dan Pengembangan LPDBKUMKM mengenai penyaluran dana bergulir bagi Koperasi simpan pinjam agribisnis di Kabupaten Majalengka dan Pengelola Koperasi simpan pinjam terkait pengelolaan dana bergulir untuk pengembangan usaha koperasi simpan pinjam agribisnis.

\section{Studi Dokumentasi}

Metode studi dokumentasi adalah metode pengumpulan data terhadap dokumen pribadi, resmi kelembagaan, referensi atau peraturan yang memiliki relevansi dengan fokus permasalahan penelitian, dan dapat dimanfaatkan untuk menguji masalah penelitian (Iskandar, 2009: 77). Studi dokumentasi ini digunakan untuk menganalisis data laporan keuangan koperasi mengenai aset, pinjaman/pembiayaan, modal, SHU, dan jumlah tenaga kerja.

\section{Metode Penarikan Sampel}

$$
\text { Populasi adalah wilayah }
$$
generalisasi yang terdiri atas obyek/subyek yang mempunyai kualitas dan karakteristik tertentu yang ditetapkan oleh peneliti untuk dipelajari dan kemudian ditarik 
kesimpulannya (Sugiyono, 2009: 61).

Sampel adalah bagian dari jumlah dan karakteristik yang dimiliki oleh populasi (Sugiyono, 2009: 62).

Pengambilan sampel dilakukan dengan menggunakan purposive sampling, yaitu penentuan sampel dengan target atau pertimbangan tertentu (Sugiyono, 2009: 68). Sampel yang diambil merupakan keseluruhan populasi, hal ini dikarenakan oleh populasi yang sedikit dan sangat spesifik

\section{HASIL DAN PEMBAHASAN}

Hasil Penelitian

\begin{tabular}{|c|l|c|c|c|c|}
\hline 1 & Ash Shofa & $\begin{array}{c}\text { Simpan } \\
\text { Pinjam }\end{array}$ & $\begin{array}{c}\text { Perdagangan, } \\
\text { Industri } \\
\text { Pengolahan. }\end{array}$ & $29-12-09$ & $100,000,000$ \\
\hline 2 & Babussalam & $\begin{array}{c}\text { Simpan } \\
\text { Pinjam }\end{array}$ & $\begin{array}{c}\text { Pertanian, } \\
\text { Peternakan, } \\
\text { Perdagangan, }\end{array}$ & $29-10-09$ & $1,000,000,000$ \\
\hline 3 & Istiqomah & $\begin{array}{c}\text { Simpan } \\
\text { Piniam }\end{array}$ & $\begin{array}{c}\text { Perdagangan, } \\
\text { Pertanian Iasa }\end{array}$ & 04-11-09 & $500,000,000$ \\
\hline 4 & Bina Insan & $\begin{array}{c}\text { Simpan } \\
\text { Pinjam }\end{array}$ & $\begin{array}{c}\text { Pertanian, } \\
\text { Industri } \\
\text { Pengolahan, } \\
\text { Pordoconaon }\end{array}$ & $23-12-09$ & $300,000,000$ \\
\hline
\end{tabular}

Sumber : Data Dokumen LPDB-KUMKM 2009

Koperasi simpan pinjam agribisnis di Kabupaten Majalengka yang menerima dana bergulir dari LPDB-KUMKM pada tahun 2009 ada 6 koperasi yaitu Koperasi Al-Amanah, Koperasi Karya Mukti, Koperasi Ash Shofa, Koperasi Babussalam, Koperasi Istiqomah, dan Koperasi Bina Insan Madani. Koperasi AlAmanah melayani pinjaman untuk usaha pertanian (tembakau, sayuran dan padi), perdagangan (pedagang pasar), dan air bersih. Koperasi Karya Mukti melayani pinjaman untuk usaha pertanian, peternakan, dan perdagangan. Koperasi Ash- Shofa melayani pinjaman untuk perdagangan, industri pengolahan, dan pertanian. Koperasi Babussalam melayani pinjaman untuk usaha pertanian, peternakan, perdagangan, dan jasa. Koperasi Istiqomah melayani pinjaman untuk usaha perdagangan, pertanian, jasa. Koperasi Bina Insan Madani melayani pinjaman untuk usaha pertanian, industri pengolahan, perdagangan, dan jasa.

Data laporan keuangan koperasi simpan pinjam agribisnis di Kabupaten Majalengka yang didapat dari data dokumen LPDB-KUMKM dan koperasi simpan pinjam agribisnis di Kabupaten Majalengka disajikan dalam bentuk tabel. Data ini berisi jumlah aset, pemberian pinjaman/pembiayaan, modal, SHU, dan 
tenaga kerja yang dibandingkan sebelum menerima dana bergulir tahun 2009 dengan setelah menerima dana bergulir tahun 2010 dan 2011. Data laporan keuangan ini kemudian dianalisis. Analisis data tersebut dilakukan untuk mengetahui berapa besar presentase pengembangan usaha koperasi simpan pinjam dan menganalisis adakah pengaruh dana bergulir terhadap pengembangan usaha koperasi simpan pinjam agribisnis. Berikut data laporan keuangan dari 2009 sampai 2011 yang disajikan dalam bentuk table.

Tabel 2. Data Aset Koperasi Simpan Pinjam Agribisnis

\begin{tabular}{|c|c|c|c|c|}
\hline \multirow[t]{2}{*}{ No } & \multirow[t]{2}{*}{ Nama Koperasi } & \multirow{2}{*}{$\begin{array}{c}\begin{array}{c}\text { Aset Sebelum } \\
\text { Menerima Dana }\end{array} \\
2009 \\
\end{array}$} & \multicolumn{2}{|c|}{$\begin{array}{c}\text { Aset Sesudah Menerima Dana } \\
\text { Bergulir }\end{array}$} \\
\hline & & & 2010 & 2011 \\
\hline 1 & AlAmanah & 3.451 .892 .851 .6 & 4.749 .126 .849 .37 & 8.418 .683 .418 .97 \\
\hline 2 & Karva Mukti & 2.851 .497 .008 & 3.799 .368 .676 .51 & 5.017 .231 .127 .82 \\
\hline 3 & Ash Shofa & 2.979 .661 .043 .92 & 3.369 .622 .403 .92 & 4.286 .781 .786 .16 \\
\hline 4 & Babussalam & 11.363 .360 .211 .8 & 10.956 .051 .988 .23 & 10.736 .930 .948 .47 \\
\hline 5 & Istiaomah & 4.574 .793 .963 & 8.853 .546 .419 & 9.203 .888 .602 \\
\hline 6 & Bina Insan Madani & 2.467 .214 .882 & 3.729 .709 .729 & 5.529 .561 .245 \\
\hline
\end{tabular}

Sumber : Data Dokumen Koperasi Simpan Pinjam Agribisnis (2011)

Berdasarkan tabel data aset koperasi simpan pinjam agribisnis dapat dilihat rata-rata nilai aset koperasi simpan pinjam agribisnis di Kabupaten Majalengka mengalami peningkatan setelah menerima dana bergulir pada tahun 2010 dan 2011. Koperasi Al-Amanah, Koperasi Karya Mukti, Koperasi Ash- Shofa, Koperasi Istiqomah, dan Koperasi Bina Insan Madani mengalami peningkatan nilai aset setelah menerima dana bergulir dilihat pada tahun 2010 dan 2011. Sedangkan
Koperasi Babussalam mengalami penurunan nilai aset setelah menerima dana bergulir dilihat pada tahun 2010 dan 2011 . Berdasarkan tabel data pemberian pinjaman/pembiayaan koperasi simpan pinjam agribisnis Koperasi Al-Amanah, Koperasi Ash-Shofa, Koperasi Istiqomah, dan Koperasi Bina Insan Madani mengalami peningkatan nilai pemberian pinjaman/pembiayaan dilihat pada tahun 2010 dan 2011. Koperasi Karya Mukti

Tabel 3. Data Pinjaman/Pembiayaan Koperasi Simpan Pinjam Agribisnis 


\begin{tabular}{|c|c|c|c|c|}
\hline \multirow[t]{2}{*}{ No } & \multirow[t]{2}{*}{$\begin{array}{c}\text { Nama } \\
\text { Koperasi }\end{array}$} & \multirow{2}{*}{$\begin{array}{c}\text { Pinjaman/Pembiayaan } \\
\text { Sebelum Menerima }\end{array}$} & \multicolumn{2}{|c|}{$\begin{array}{c}\text { Pinjaman/Pembiayaan Sesudah } \\
\text { Menerima Dana Bergulir }\end{array}$} \\
\hline & & & 2010 & 2011 \\
\hline 1 & AlAmanah & 1.854 .367 .125 & 3.229 .304 .634 & 5.852 .287 .566 \\
\hline 2 & Karva Mukti & 3.463 .339 .050 & 4.458 .751 .200 & 3.101 .425 .000 \\
\hline 3 & Ash Shofa & 825.535 .460 & 1.106 .657 .630 & 2.003 .797 .774 \\
\hline 4 & Babussalam & 7.860 .564 .285 .97 & 7.435 .161 .274 .80 & 7.286 .458 .049 .30 \\
\hline 5 & Istigomah & 3.127 .500 .000 & 4.818 .700 .000 & 7.771 .500 .000 \\
\hline 6 & Bina Insan & $1,866,636,106$ & $2,903,137,746$ & $3,419,475,329$ \\
\hline
\end{tabular}

Sumber : Data Dokumen Koperasi Simpan Pinjam Agribisnis (2011)

mengalami peningkatan nilai pemberian pinjaman/pembiayaan setelah menerima dana bergulir pada tahun 2010 namun mengalami penurunan pada tahun 2011. Koperasi Babussalam mengalami penurunan nilai pemberian pinjaman/pembiayaan setelah menerima dana bergulir dilihat pada tahun 2010 dan 2011.

Tabel 4. Data Modal Sendiri Koperasi Simpan Pinjam Agribisnis

\begin{tabular}{|c|c|c|c|c|}
\hline \multirow[t]{2}{*}{ No } & \multirow[t]{2}{*}{ Nama Koperasi } & \multirow{2}{*}{$\begin{array}{c}\text { Modal Sebelum } \\
\text { Menerima Dana } \\
\text { Bergulir }\end{array}$} & \multicolumn{2}{|c|}{$\begin{array}{c}\text { Modal Sesudah Menerima Dana } \\
\text { Bergulir }\end{array}$} \\
\hline & & & 2010 & 2011 \\
\hline 1 & Al Amanah & $223,295,321.33$ & $378,070,407.71$ & $635,626,028.07$ \\
\hline 2 & Karya Mukti & $227,514,779$ & $229,427,227.50$ & $549,890,463.30$ \\
\hline 3 & Ash Shofa & $196,988,116$ & $216,161,140.53$ & $506,654,668.53$ \\
\hline 4 & Babussalam & $1,079,555,499.33$ & $1,101,907,926.53$ & $1,212,098,719.54$ \\
\hline 5 & Istiqomah & $279,105,745$ & $331,705,983$ & $426,515,913$ \\
\hline 6 & $\begin{array}{ll}\text { Bina } & \text { Insan } \\
\text { Madani } & \end{array}$ & $234,450,870$ & $282,273,916$ & $416,832,756$ \\
\hline
\end{tabular}

Sumber : Data Dokumen Koperasi Simpan Pinjam Agribisnis (2011)

Berdasarkan tabel data modal sendiri koperasi simpan pinjam agribisnis ratarata nilai modal sendiri koperasi simpan pinjam agribisnis di Kabupaten Majalengka mengalami peningkatan dilihat pada tahun 2010 dan 2011. Keseluruhan koperasi mengalami peningkatan modal sendiri namun peningkatannya tidak terlalu signifikan. 
Tabel 5. Data SHU Koperasi Simpan Pinjam Agribisnis

\begin{tabular}{|c|c|c|c|c|}
\hline No & Nama Koperasi & $\begin{array}{c}\text { SHU Sebelum } \\
\text { Menerima }\end{array}$ & \multicolumn{2}{|c|}{$\begin{array}{c}\text { SHU Sesudah Menerima } \\
\text { Dana Bergulir }\end{array}$} \\
\hline & & 2009 & 2010 & 2011 \\
\hline 1 & Al Amanah & $27,459,479$ & $44,437,692$ & $61,898,883$ \\
\hline 2 & Karya Mukti & $134,172,409.45$ & $144,264,201.71$ & $25,463,506.8$ \\
\hline 3 & Ash Shofa & $19,155,024.91$ & $41,511,672.02$ & $38,216,761.14$ \\
\hline 4 & Babussalam & $113,340,850.38$ & $155,451,236.91$ & $18,654,148.43$ \\
\hline 5 & Istiqomah & $36,827,513$ & $45,428,491$ & $87,482,379$ \\
\hline 6 & Bina Insan Madani & $26,590,056$ & $25,172,761$ & $27,112,658$ \\
\hline
\end{tabular}

Sumber : Data Dokumen Koperasi Simpan Pinjam Agribisnis (2011)

Berdasarkan tabel data SHU koperasi simpan pinjam agribisnis Koperasi AlAmanah, Koperasi Ash-Shofa, Koperasi Koperasi Istiqomah mengalami peningkatan SHU setelah menerima dana bergulir dilihat pada tahun 2010 dan 2011. Koperasi Karya Mukti mengalami peningkatan setelah menerima dana bergulir pada tahun 2010 namun mengalami penurunan pada tahun 2011. Koperasi Bina Insan Madani mengalami penurunan setelah menerima dana bergulir pada tahun 2010 namun mengalami peningkatan pada tahun 2011.

Tabel 6. Data Tenaga Kerja Koperasi Simpan Pinjam Agribisnis

\begin{tabular}{|l|l|l|l|l|}
\hline No & \multicolumn{1}{|c|}{ Nama Koperasi } & \multicolumn{1}{|c|}{$\begin{array}{c}\text { Tenaga Kerja } \\
\text { Sebelum } \\
\text { Menerima Dana } \\
\text { Bergulir }\end{array}$} & \multicolumn{2}{|c|}{$\begin{array}{c}\text { Tenaga Kerja Sesudah } \\
\text { Menerima Dana Bergulir }\end{array}$} \\
\cline { 3 - 5 } & \multicolumn{1}{|c|}{$\mathbf{2 0 0 9}$} & \multicolumn{2}{|c|}{$\mathbf{2 0 1 0}$} & 17 \\
\hline 1 & Al Amanah & 9 & 13 & 13 \\
\hline 2 & Karya Mukti & 12 & 13 & 11 \\
\hline 3 & Ash Shofa & 5 & 8 & 31 \\
\hline 4 & Babussalam & 22 & 31 & 13 \\
\hline 5 & Istiqomah & 8 & 9 & 16 \\
\hline 6 & Bina Insan Madani & 12 & 14 & \\
\hline
\end{tabular}

Sumber : Data Dokumen Koperasi Simpan Pinjam Agribisnis (2011) 
Berdasarkan tabel data tenaga kerja koperasi simpan pinjam agribisnis ratarata jumlah tenaga kerja koperasi simpan pinjam agribisnis di Kabupaten Majalengka mengalami peningkatan setelah menerima dana bergulir dilihat pada tahun 2010 dan 2011. Keseluruhan koperasi mengalami peningkatan jumlah tenaga kerja namun peningkatannya tidak terlalu signifikan.

\section{Proses Penyaluran Dana Bergulir LPDB-KUMKM Bagi Koperasi}

\section{Simpan Pinjam}

Proses penyaluran dana bergulir LPDBKUMKM kepada koperasi simpan pinjam yaitu pengajuan proposal dengan data lengkap, analisa kelayakan usaha, OTS (on the spot), analisa bisnis, legal, dan opini risiko, komite pinjaman/pembiayaan, SP3, akad pinjaman/pembiayaan, pencairan, monitoring dan evaluasi. Pengajuan proposal dengan data lengkap diberikan langsung oleh calon mitra ke LPDBKUMKM sesuai persyratan yang telah ditentukan. Analisa kelayakan usaha diproses oleh Divisi Bisnis. OTS (On The Spot) dilaksanakan oleh Divisi Manajemen Resiko untuk melihat kondisi calon mitra. Analisia bisnis dilaksanakan oleh Divisi Bisnis, analisa legal dilaksanakan oleh Divisi Hukum, analisa resiko dilaksnakan oleh Divisi Manajemen Resiko. Komite pinjaman/pembiayaan dilaksanakan untuk pemutusan pinjaman. SP3 dibuatkan oleh Divisi Hukum. Akad pinjaman/pembiayaan dibuatkan oleh Divisi Hukum dan ditandatangani oleh pihak LPDB-KUMKM dan calon mitra. Pencairan dilaksanakan melalui Bank sesuai perjanjian. Monitoring dan evaluasi dilaksanakan oleh Divisi Evaluasi dan Pengkajian untuk memantau perkembangan koperasi setelah menerima dana bergulir dari LPDB-KUMKM.

Flow chart penyaluran tiap proses disajikan dalam Lampiran.

Berikut gambar proses penyaluran dana bergulir LPDB-KUMKM bagi koperasi simpan pinjam. 


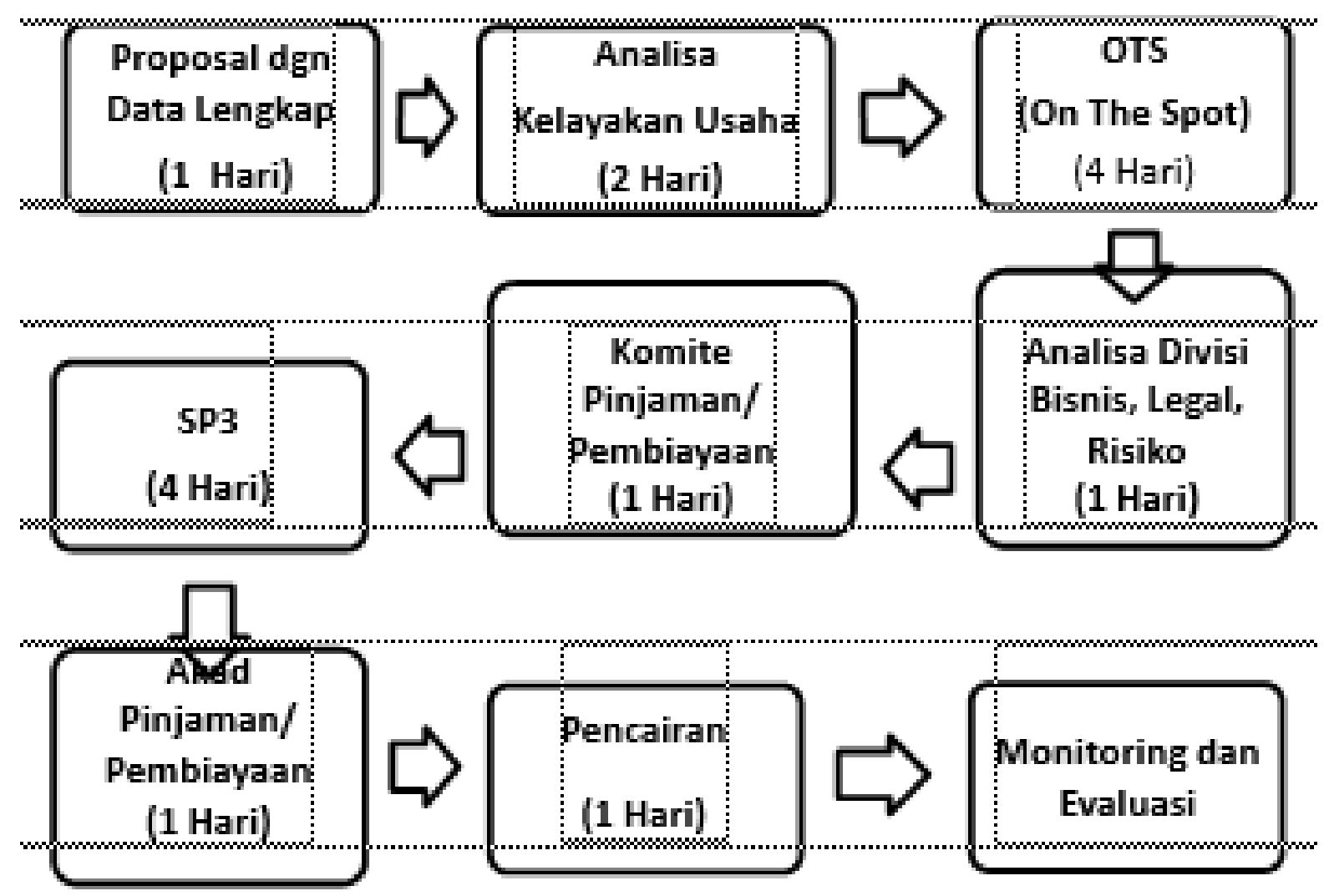

Gambar 5. Proses Penyaluran Pinjaman/Pembiayaan LPDB-KUMKM

2) Melaksanakan RAT

c. Melayani jumlah anggota paling sedikit

1. Proposal Dengan Data Lengkap

Untuk menyalurkan dana bergulir koperasi simpan pinjam agribisnis harus mengajukan proposal kepada LPDBKUMKM. Persyaratan KSP/USP Koperasi dan/atau KJKS/UJKS Koperasi yang dapat diberikan Pinjaman/Pembiayaan oleh LPDB-KUMKM adalah sebagai berikut :

a. Telah berbadan hukum

b. Berpengalaman menjalankan usaha simpan sekurang- kurangnya 3 (tiga) tahun, terutama terkait dengan tujuan penggunaan pinjaman/pembiayaan dan memiliki kinerja baik selama 2 (dua) tahun terakhir yang ditunjukan dengan:

1) Memperoleh SHU yang positif.
20 orang

d. Untuk seluruh Pinjaman/Pembiayaan atau dalam bentuk lainnya, dengan plafond di atas Rp. 1.000.000.000,- (satu milyar rupiah), harus dilengkapi dengan laporan keuangan audited minimal 2 (dua) tahun terakhir, dengan opini "minimal wajar dengan pengecualian"

e. Bersedia menandatangani surat perjanjian secara notariil.

f. Pinjaman/pembiayaan yang diberikan oleh LPDB-KUMKM kepada KSP/USP Koperasi dan/atau KJKS/UJKS Koperasi adalah pinjaman/pembiayaan dengan pola executing, dimana risiko kegagalan atas pinjaman/pembiayaan tersebut menjadi 
tanggung jawab KSP/USP dan/atau KJKS/UJKS Koperasi.

Persyaratan calon Usaha Mikro dan Kecil penerima pinjaman dari KSP/USP Koperasi dan/atau KJKS/UJKS Koperasi adalah :

a. Menjalankan usaha produktif.

b. Memenuhi kriteria Usaha Mikro atau Kecil sesuai peraturan perundangan yang berlaku

c. Usahanya layak sesuai penilaian KSP/USP Koperasi Primer, dan/atau KJKS/UJKS Koperasi Primer

1) Photo copy Akta Pendirian dan/atau perubahan anggaran dasar beserta SK pengesahannya.

2) Photo copy ijin usaha yang akan dibiayai.

3) Susunan pengurus dan pengawas yang diketahui oleh SKPD.

4) Photo copy Surat keterangan domisili dan/atau Surat Ijin Tempat Usaha (SITU) 5) Photo copy NPWP.

6) Photo copy Tanda Daftar Perusahaan (TDP) koperasi.

7) Photo copy bukti kepemilikan kantor.

d. Laporan pertanggung jawaban pengurus KSP/USP Koperasi dan/atau KJKS/UJKS Koperasi sesuai hasil RAT tahun buku terakhir

e. Photo copy KTP pengurus dan pengawas Koperasi dengan hasil RAT tahu buku terakhir

f. Laporan keuangan 2 (dua) tahun terakhir bagi KSP/USP Koperasi dan/atau KJKS/UJKS Koperasi yang mengajukan plafond pinjaman/pembiayaan Rp1.000.000.000,- (satu milyar rupiah) ke atas g. Photo copy sertifikat penilaian kesehatan KSP/USP Koperasi dan/atau KJKS/UJKS Koperasi yang dikeluarkan oleh pejabat berwenang 2 (dua) tahun terakhir.

Surat permohonan dan proposal yang masuk akan diproses oleh Divisi Bisnis untuk dilakukan verifikasi dan pengecekan kelengkapan data dengan ketentuan, yaitu :

a. Proposal yang memenuhi mandatory dan datanya lengkap akan diproses selanjutnya untuk analisa kelayakan usaha.

b. Proposal yang memenuhi mandatory tapi datanya tidak lengkap, akan dibuatkan surat kelengkapan data oleh Divisi Umum (Tata Usaha) dan dikirimkan kepada calon mitra LPDBKUMKM agar dokumenya dilengkapi. Setelah dilengkapi dokumen tersebut akan diproses selanjutnya untuk analisa kelayakan usaha.

c. Proposal yang tidak memenuhi mandatory akan dibuatkan surat penolakan oleh Divisi Umum (Tata Usaha) dan dikirimkan kepada calon mitra LPDBKUMKM.

2. Analisis Kelayakan Usaha

Proposal yang memenuhi mandatory dan datanya lengkap akan diproses oleh Divisi Bisnis untuk dilakukan analisa kelayakan usaha, dengan ketentuan yaitu :

a. Proposal yang layak usaha akan diproses selanjutnya oleh Divisi Bisnis

b. Proposal yang tidak layak usaha akan dibuatkan surat penolakan oleh Divisi Bisnis dan dikirimkan oleh Divisi Umum (Tata Usaha) 
kepada calon mitra LPDBKUMKM. Analisis kelayakan usaha calon mitra LPDB-KUMKM ini dilakukan oleh LPDBKUMKM dan/atau menggunakan jasa pihak ketiga/konsultan yang ditetapkan oleh LPDB-KUMKM dengan memperhatikan aspek yaitu manajemen dan organisasi, usaha dan produksi, pasar, yuridis, dan keuangan.

\section{On The Spot (OTS)}

Proposal yang layak usaha akan dilakukan On The Spot (OTS) atau survey untuk melihat kodisi usaha koperasi yang akan diberikan pinjaman. OTS ini dilakukan untuk menentukan bisa tidaknya calon mitra koperasi tersebut diberikan pinjaman termasuk menentukan besarnya pinjaman. Hasil OTS ini selanjutnya akan diberikan kepada pihak Komite untuk diberikan putusan diterima atau ditolak.

4. Analisa Bisnis, Analisa Yuridis, dan Opini Risiko

Laporan OTS akan diproses oleh Divisi Bisnis untuk ditentukan layak atau tidaknya dengan ketentuan yaitu :

a. Calon mitra yang layak bisnis akan diproses oleh Divisi Hukum untuk dilakukan analisa yuridis dan Divisi Manajemen risiko untuk dibuatkan opini risiko. Hasil analisa yuridis dan opini risiko akan diproses untuk dibuatkan memorandum pinjaman/pembiayaan oleh Sekretaris Komite b. Calon mtra yang tidak layak bisnis akan dibuatkan surat penolakan oleh Divisi Umum (Tata Usaha) dan dikirimkan kepada calon mitra LPDB-KUMKM

5. Komite Pinjaman/Pembiayaan

Memorandum Pinjaman/Pembiayaan, analisa yuridis dan opini risiko akan diproses oleh Komite Pinjaman/Pembiyaan. Komite Pinjaman/Pembiayaan akan melakukan rapat dengan anggotanya untuk menentukan persetujuan atas pinjaman/pembiayaan calon mitra LPDBKUMKM dengan ketentuan :

a. Calon mitra LPDB-KUMKM yang disetujui akan dibuatkan memorandum Komite Pinjaman/Pembiayaan dan diproses oleh Divisi Bisnis dan Divisi Hukum.

b. Calon mitra LPDB-KUMKM yang tidak disetujui akan dibuatkan surat penolakan dan dikirimkan kepada calon mitra LPDB- KUMKM.

Keputusan atas pemberian Pinjaman/Pembiayaan dari LPDBKUMKM kepada Koperasi sepenuhnya merupakan kewenangan LPDB- KUMKM yang dilakukan oleh Komite dan diberitahukan kepada koperasi yang bersangkutan. Waktu untuk proses putusan komite pinjaman/pembiayaan dilaksanakan selama 1 hari kerja.

6. Surat Pemberitahuan Persetujuan Prinsip (SP3)

Memorandum

Komite

Pinjaman/Pembiayaan akan diproses oleh Divisi Hukum dengan membuat Surat Pemberitahuan Persetujuan Prinsip (SP3) 
kepada calon mitra LPDB-KUMKM. SP3

tersebut berisi ketentuan dan persyaratan yaitu :

a. Nama mitra

b. No. Badan Hukum

c. Plafon Pinjaman

d. Tujuan Penggunaan

e. Jangka Waktu

f. Bentuk pinjaman

g. Setting pinjaman

h. Tingkat suku bunga

i. Denda keterlambatan

j. Pola penarikan

k. Biaya-biaya

1. Jaminan

m. Persyaratan yang harus dipenuhi sebelum penandatanganan perjanjian pinjaman

n. Syarat penarikan

o. Jadwal pembayaran kembali

p. Pelunasan lebih awal atau sebelum jatuh tempo

q. Persyaratan pinjaman

r. Monitoring dan evaluasi

s. Pengikatan

t. Lain-lain

Surat ini ditandatangani oleh Direktur Bisnis dan Ketua Pengurus Koperasi Draft SP3 yang telah ditandatangani Direktur Utama kemudian dikirim oleh Divisi Hukum kepada calon mitra LPDBKUMKM dengan ketentuan yaitu :

a. SP3 yang disetujui oleh calon mitra LPDB-KUMKM akan ditandatangani dan dikirim kembali ke Divisi Umum (Tata Usaha) untuk diproses selanjutnya. b. SP3 yang tidak disetujui oleh calon mitra LPDB-KUMKM akan dikirimkan kembali ke Divisi Umum (Tata Usaha) dan dibuatkan surat pembatalan SP3

7. Akad Pinjaman/Pembiayaan

Koperasi yang telah disetujui memperoleh pinjaman/pembiayaan dari LPDBKUMKM wajib menandatangani perjanjian pinjaman/pembiayaan yang dibuat secara notariil atau dibawah tangan. Dalam akad pinjaman/pembiayaan berisi persyaratan yaitu : a. Menggunakan fasilitas pinjaman LPDB-KUMKM sesuai permohonan pembiayaan usaha yang disetujui oleh LPDB-KUMKM.

b. Koperasi diwajibkan merealisasikan pinjaman yang diperoleh dari LPDBKUMKM dalam jangka waktu 60 hari kalender sejak dana pinjaman dari LPDBKUMKM diterima pada rekening Koperasi, apabila melebihi jangka waktu tersebut maka dana akan ditarik kembali.

c. Koperasi wajib menyerahkan daftar persediaan barang milik koperasi yang menjadi Jaminan Fidusia, setiap 6 bulan sekali, dengan nilai minimal sebesar $100 \%$ dari outstanding pinjaman, apabila melebihi jangka waktu tersebut maka dana akan ditarik kembali.

d. Dalam hal koperasi tidak menggunakan seluruh atau sebagian pinjaman sesuai tujuan penggunaan dana maka koperasi wajib mengembalikan pinjaman yang tidak terpakai kepada LPDB- KUMKM, atau LPDB-KUMKM dapat menarik pinjaman tersebut. 
e. Menyerahkan Laporan Keuangan tahunan unaudited, selambat- lambatnya akhir bulan Maret.

f. LPDB-KUMKM berhak mengunjungi koperasi dan objek barang yang dibiayai.

g. Memberitahukan secara tertulis kepada LPDB-KUMKM apabila melakukan perubahan susunan pengurus dan menerima pinjaman baru atau tambahan pinjaman dari lembaga keuangna lain, baik dengan atau tanpa jaminan.

h. Pengurus wajib menyampaikan dalam Rapat Anggota Tahunan (RAT) bahwa apabila ada perubahan susunan pengurus karena sebab apapun juga selama jangka waktu pinjaman belum berakhir maka pengurus baru harus bersedia menandatangani Personal Guarantee.

i. Pemberian pinjaman ini tidak melanggar ketentuan atau syarat-syarat pinjaman yang telah ditandatangani oleh koperasi dengan pihak dan/atau kreditur lain.

j. Seluruh persyaratan pinjaman harus dipenuhi dan sesuai dengan Peraturan Direksi LPDB-KUMKM No. 36/PER/LPDB/2010, Tentang Petunjuk Teknis Pemberian Pinjaman/Pembiayaan Kepada Koperasi.

8. Pencairan

Setelah koperasi menandatangani akad pinjaman/pembiayaan, LPDB- KUMKM melakukan pencairan uang di Bank dan membuka rekening atas nama Koperasi yang bersangkutan di Bank tersebut. Pencairan dana tersebut dikirimkan ke rekening Koperasi yang jumlahnya sesuai dengan perjanjian pinjaman/pembiayaan.

9. Monitoring dan Evaluasi
Setelah koperasi mendapatkan pinjaman dana bergulir, LPDB- KUMKM melakukan monitoring dan evaluasi kepada koperasi tersebut. Ketentuan Monitoring dan Evaluasi adalah :

a. Koperasi wajib menyampaikan laporan realisasi penyaluran Pinjaman/Pembiayaan kepada LPDB-KUMKM paling lambat 75 (tujuh puluh lima) hari kalender setelah pencairan.

b. Koperasi wajib menyampaikan laporan perkembangan Pinjaman/Pembiayaan setiap 3 (tiga) bulan kepada LPDB-KUMKM.

Proses penyaluran dana bergulir bagi koperasi simpan pinjam agribisnis di Kabupaten Majalengka disajikan dalam Lampiran. Tabel data penyaluran itu menunjukan tahap waktu penyaluran dana bergulir dari LPDB-KUMKM bagi koperasi simpan pinjam agribisnis di Kabupaten Majalengka. Tahap waktu penyaluran untuk tiap koperasi simpan pinjam agribisnis di Kabupaten Majalengka berbeda. Koperasi A1Amanah dan Koperasi Karya Mukti mengajukan proposal ke LPDB-KUMKM pada tanggal 25 Februari 2009 dan dicairkan pada tanggal 16 Desember 2009. Koperasi Ash Shofa mengajukan proposal ke LPDB-KUMKM pada tangal 27 Januari 2009 dan dicairkan pada tanggal 29 Desember 2009. Koperasi Babussalam mengajukan proposal ke LPDB-KUMKM pada tanggal 22 Oktober 2009 dan dicairkan 29 Oktober 2009. Koperasi Istiqomah mengajukan proposal ke LPDB-KUMKM 
pada tahun 2009 dan dicairkan pada tanggal

4 November 2009. Koperasi Bina Insan Madani mengajukan proposal ke LPDBKUMKM pada tahun 2009 dan dicairkan pada tanggal 23 Desember 2009.

Jumlah pencairan untuk tiap koperasi simpan pinjam agribisnis di Kabupaten Majalengka juga berbeda sesuai hasil penilaian dari komite pinjaman/pembiayaan LPDB-KUMKM yang dilihat dari segi kelayakan usaha koperasi. Koperasi Al-Amanah mengajukan pinjaman ke LPDB-KUMKM sebesar Rp500.000.000 dan jumlah pencairannya hanya Rp300.000.000. Koperasi Karya Mukti mengajukan pinjaman ke LPDBKUMKM sebesar Rp500.000.000 dan jumlah pencairannya hanya Rp250.000.000. Koperasi Ash Shofa mengajukan pinjaman ke LPDB-KUMKM sebesar Rp1.000.000.000 dan dicairkan hanya Rp100.000.000. Koperasi Babussalam mengajukan pinjaman ke LPDB-KUMKM sebesar Rp1.000.000.000 dan dicairkan sebesar Rp1.000.000.000. Koperasi Istiqomah mengajukan pinjaman ke LPDB-KUMKM sebesar Rp500.000.000 dan dicairkan sebesar Rp500.000.000. Koperasi Bina Insan Madani mengajukan pinjaman ke LPDBKUMKM sebesar Rp400.000.000 dan dicairkan sebesar sebesar Rp300.000.000.

Presentase Pengembangan Usaha Koperasi Simpan Pinjam Agribisnis Analisis presentase pengembangan usaha koperasi simpan pinjam agribisnis di Kabupaten Majalengka menggunakan alat analisis Ms. Excel 2007. Berikut hasil perhitungan presentase pengembangan usaha koperasi simpan pinjam agribisnis.

1. Presentase Pengembangan Aset

$\begin{array}{lr}\text { Menghitung } & \text { presentase } \\ \text { pengembangan aset } & \text { koperasi }\end{array}$ simpan pinjam agribisnis di Kabupaten Majalengka berdasarkan nilai aset sebelum menerima dana bergulir (2009) dengan sesudah menerima dana bergulir pada tahun pertama (2010) dan tahun kedua (2011) (dalam Tabel 2) adalah sebagai berikut :

a. Pengembangan Aset Tahun Pertama (2010)

As $0=27,688,419,960.32$

As1 $=35,457,426,066.03$

$\%$ Pengembangan Aset $=$

(As1 - As0) X100\%

As0

$=28.06 \%$

Berdasarkan hasil perhitungan menggunakan rumus presentase pengembangan usaha, nilai aset koperasi simpan pinjam agribisnis di Kabupaten Majalengka pada tahun pertama setelah menerima dana bergulir mengalami peningkatan yaitu sebesar $28.06 \%$.

b. Pengembangan Aset Tahun Kedua (2011)

As0 $=27,688,419,960.32$

As1 $=43,193,077,128.42$ 
$\%$ Pengembangan Aset $=$

$$
\begin{aligned}
& \frac{\text { As } 1-\text { As } 0}{\text { As } 0} \times 100 \% \\
& =55.99 \%
\end{aligned}
$$

Berdasarkan hasil perhitungan menggunakan rumus presentase pengembangan usaha, nilai aset koperasi simpan pinjam agribisnis di Kabupaten Majalengka pada tahun kedua setelah menerima dana bergulir mengalami peningkatan yaitu sebesar $55.99 \%$.

\section{Pembahasan}

Pembahasan hasil penelitian ini menggunakan teori-teori yang sebelumnya dijelaskan sebagai dasar dari penelitian dan kemudian dibandingkan dengan hasil analisis data yang didapat.

\section{Proses Penyaluran Dana Bergulir LPDB-KUMKM Bagi Koperasi}

\section{Simpan Pinjam}

Menurut Peraturan Menteri Keuangan No.99/PMK.05/2008 Pasal 6, ketentuan penyaluran dana bergulir yaitu :

1. PA

(Pengguna

Anggaran)/pimpinan Satker BLU dapat menyalurkan dana bergulir kepada penerima dana bergulir dengan atau tanpa lembaga perantara.

2. Lembaga perantara dapat berupa lembaga keuangan bank atau lembaga keuangan non-bank.

3. Lembaga perantara dapatberfungsi sebagai penyalur dana (channeling) atau pelaksana pengguliran dana (executing).

4. Lembaga perantara berfungsi sebagai penyalur dana (channeling) dalam hal lembaga tersebut hanya menyalurkan dana bergulir kepada penerima dana bergulir dan tidak bertanggungjawab menetapkan penerima dana.

5. Lembaga perantara berfungsi sebagai pelaksana pengguliran dana (executing) dalam hal lembaga tersebut mempunyai tanggung jawab menyeleksi dan menetapkan penerima dana bergulir, menyalurkan dan menagih kembali dana bergulir, serta menanggung risiko terhadap ketidaktertagihan dana bergulir.

Hasil penelitian menunjukan ketentuan penyaluran dana bergulir LPDB- KUMKM bagi Koperasi simpan pinjam yaitu :

1. LPDB-KUMKM menyalurkan dana bergulir ke koperasi simpan pinjam.

2. Koperasi simpan pinjam berfungsi sebagai pelaksana pengguliran dana (executing) yang mempunyai tanggung jawab 


\begin{abstract}
menyeleksi dan menetapkan penerima dana bergulir, menyalurkan dan menagih kembali dana bergulir, serta menanggung risiko terhadap ketidaktertagihan dana bergulir.
\end{abstract}

3. Koperasi simpan pinjam berkewajiban mengembalikan dana bergulir tersebut ke LPDBKUMKM.

Berdasarkan SOP yang ditetapkan oleh Direksi LPDB-KUMKM, proses penyaluran dana bergulir membutuhkan waktu yaitu 1 hari kerja untuk pengecekan proposal dengan data lengkap , 2 hari kerja untuk analisa kelayakan usaha, 1 hari kerja untuk On The Spot (OTS) ke koperasi simpan pinjam, 1 hari kerja untuk analisa divisi bisnis, legal, dan resiko, 1 hari kerja untuk komite pinjaman/pembiayaan, 4 hari kerja untuk Surat Pemberitahuan Persetujuan (SP3), 1 hari kerja untuk akad pinjaman/pembiayaan, dan 1 hari kerja untuk pencairan.

Hasil penelitian menunjukan dalam pelaksanaan penyaluran dana bergulir waktu penyaluran dana bergulir tidak sesuai dengan SOP. Koperasi Al-Amanah dan Koperasi Karya Mukti mengajukan proposal ke LPDBKUMKM pada tanggal 25 Februari 2009 dan dicairkan pada tanggal 16 Desember 2009. Koperasi Ash Shofa mengajukan proposal ke LPDB-KUMKM pada tangal 27 Januari 2009 dan dicairkan pada tanggal 29 Desember 2009. Koperasi Babussalam mengajukan proposal ke LPDB-KUMKM pada tanggal 22 Oktober 2009 dan dicairkan 29 Oktober 2009. Koperasi Istiqomah mengajukan proposal ke LPDB-KUMKM pada tahun 2009 dan dicairkan pada tanggal 4 November 2009. Koperasi Bina Insan Madani mengajukan proposal ke LPDB-KUMKM pada tahun 2009 dan dicairkan pada tanggal 23 Desember 20009. Kendala yang dihadapi di lapangan adalah seringnya koperasi simpan pinjam yang mengajukan pinjaman kepada LPDB-KUMKM data dokumennya tidak lengkap. Hal ini menyebabkan waktu proses penyaluran lebih lama dan tidak tepat waktu sesuai SOP LPDBKUMKM karena pihak koperasi simpan pinjam harus melengkapi dokumen sesuai ketentuan LPDB-KUMKM. LPDB-KUMKM sendiri telah membuat Standar Operasional Kerja sesuai ISO 9001 : 2008 agar penyaluran dana bergulir tepat waktu.

\section{Pengaruh Penyaluran Dana Bergulir Terhadap Pengembangan Usaha} Koperasi Simpan Pinjam Agribisnis 
Menurut Peraturan Menteri Keuangan No.99/PMK.05/2008 Pasal 2, tujuan dari dana bergulir adalah untuk membantu perkuatan modal usaha guna pengembangan koperasi, usaha mikro, kecil, menengah, dan usaha lainnya dalam upaya penanggulangan kemiskinan, pengangguran, dan pengembangan ekonomi nasional. Menurut Urhen (2011) tujuan dana bergulir adalah membantu perkuatan modal usaha guna pemberdayaan koperasi dan UMKM, meningkatkan aktivitas ekonomi pedesaan, meningkatkan volume usaha koperasi dan UKM, meningkatkan penyerapan tenaga kerja, meningkatkan semangat koperasi, meningkatkan pendapatan anggota, dan membangkitkan etos kerja.

Berdasarkan Peraturan Direksi LPDBKUMKM, tujuan LPDB-KUMKM memberikan layanan berupa pinjaman kepada koperasi simpan pinjam adalah :

1. Memperluas akses pinjaman/pembiayaan kepada Usaha Mikro Kecil melalui KSP/USP Koperasi dan/atau KJKS/UJKS Koperasi

2. Memperkuat permodalan KSP/USP Koperasi dan/atau KJKS/UJKS Koperasi dalam melayani pemberian pinjaman/pembiayaan kepada Usaha Mikro Kecil

3. Memperkuat peran KSP/USP Koperasi dan/atau KJKS/UJKS Koperasi dalam mendukung upaya perluasan kesempatan kerja dan pengentasan kemiskinan.

Berdasarkan beberapa teori diatas, dana bergulir memiliki pengaruh terhadap pengembangan usaha koperasi yang dilihat dengan meningkatnya akses pinjaman/pembiayaan, meningkatnya modal, meningkatnya pendapatan (SHU), dan menaggulangi pengangguran. Hasil penelitian ini menunjukan yaitu :

1. Pengaruh Dana Bergulir Terhadap Pengembangan Aset

Pada tahun pertama (2010) setelah menerima dana bergulir aset koperasi mengalami kenaikan sebesar 28.06\%. Hasil perhitungan menggunakan rumus uji $t$ berpasangan (paired sample $t$ test) menyatakan bahwa tidak ada perbedaan aset sebelum menerima dana bergulir dengan sesudah menerima dana bergulir pada tahun pertama (2010). Setelah menerima dana bergulir nilai aset koperasi meningkat tetapi meningkatnya karena dana bergulir ini tidak berpengaruh untuk nilai aset pada seluruh sampel koperasi simpan pinjam agribisnis di Kabupaten Majalengka.

Pada tahun kedua (2011) setelah menerima dana bergulir aset koperasi mengalami kenaikan sebesar 55.99\%. Hasil perhitungan menggunakan rumus uji $t$ berpasangan (paired sample $\mathrm{t}$ test) menyatakan bahwa ada perbedaan aset antara sebelum menerima dana bergulir dengan sesudah menerima dana bergulir pada tahun kedua (2011) yang artinya dana bergulir berpengaruh terhadap pengembangan aset koperasi simpan pinjam agribisnis di Kabupaten Majalengka.

Hal ini dapat dilihat di lapangan dengan adanya kantor baru milik koperasi yang dibuat pada tahun kedua (2011) setelah 
menerima dana bergulir . Koperasi yang memiliki kantor baru yaitu Koperasi AshShofa, Koperasi Al-Amanah, dan Koperasi Bina Insan Madani. Selain itu simpanan koperasi di beberapa bank juga mengalami peningkatan.

2. Pengaruh Penyaluran Dana Bergulir Terhadap Pinjaman/Pembiayaan

Pada tahun pertama (2010) setelah menerima dana bergulir nilai pinjaman/pembiayaan koperasi mengalami kenaikan sebesar $\quad 26.07 \%$. Hasil perhitungan menggunakan rumus uji $t$ berpasangan (paired sample $t$ test) menyatakan bahwa ada perbedaan pinjaman/pembiayaan sebelum menerima dana bergulir dengan sesudah menerima dana bergulir pada tahun pertama (2010) yang artinya dana bergulir berpengaruh terhadap pengembangan pinjaman/pembiayaan koperasi simpan pinjam agribisnis di Kabupaten Majalengka.

Pada tahun kedua (2011) setelah menerima dana bergulir pinjaman/pembiayaan koperasi mengalami kenaikan sebesar $54.96 \%$. Hasil perhitungan menggunakan rumus uji $\mathrm{t}$ berpasangan (paired sample $\mathrm{t}$ test) menyatakan bahwa tidak ada perbedaan pinjaman/pembiayaan sebelum menerima dana bergulir dengan sesudah menerima dana bergulir pada tahun kedua (2011). Setelah menerima dana bergulir nilai pinjaman/pembiayaan koperasi meningkat tetapi meningkatnya karena dana bergulir ini tidak berpengaruh untuk nilai pinjaman/pembiayaan pada seluruh sampel koperasi simpan pinjam agribisnis di Kabupaten Majalengka.

Pengaruh dana bergulir terhadap pinjaman/pembiayaan hanya pada tahun pertama setelah menerima dana bergulir. Hal ini dikarenakan dana bergulir harus langsung disalurkan kepada anggota UMKM dalam jangka waktu paling lama 60 hari kalender sejak menerima dana bergulir.

Sehingga pada tahun kedua dana bergulir ini tidak berpengaruh terhadap pengembangan pinjaman/pembiayaan koperasi simpan pinjam agribisnis di Kabupaten Majalengka.

3. Pengaruh Penyaluran Dana Bergulir Terhadap Pengembangan Modal

\section{Sendiri Koperasi}

Pada tahun pertama (2010) setelah menerima dana bergulir modal sendiri koperasi mengalami kenaikan sebesar $13.33 \%$. Hasil perhitungan menggunakan rumus uji $\mathrm{t}$ berpasangan (paired sample $\mathrm{t}$ test) menyatakan bahwa tidak ada perbedaan modal sendiri koperasi sebelum menerima dana bergulir dengan sesudah menerima dana bergulir pada tahun pertama (2010). Setelah menerima dana bergulir nilai modal sendiri koperasi meningkat tetapi meningkatnya karena dana bergulir ini tidak berpengaruh untuk modal sendiri pada seluruh sampel koperasi 
simpan pinjam agribisnis di Kabupaten Majalengka.

Pada tahun kedua (2011) setelah menerima dana bergulir aset koperasi mengalami kenaikan sebesar 67.24\%. Hasil perhitungan menggunakan rumus uji $t$ berpasangan (paired sample $t$ test) menyatakan bahwa ada perbedaan modal sendiri koperasi antara sebelum menerima dana bergulir dengan sesudah menerima dana bergulir pada tahun kedua (2011) yang artinya dana bergulir berpengaruh terhadap pengembangan modal sendiri koperasi simpan pinjam agribisnis di Kabupaten Majalengka.

Hal ini dapat dilihat di lapangan pada tahun kedua terjadi penambahan anggota koperasi sehingga menambah simpanan pokok, simpanan wajib, dan dana cadangan yang berasal dari anggota koperasi.

4. Pengaruh Penyaluran Dana Bergulir Terhadap Pengembangan SHU

Pada tahun pertama (2010) setelah menerima dana bergulir nilai SHU koperasi mengalami kenaikan sebesar $27.61 \%$. Hasil perhitungan menggunakan rumus uji $t$ berpasangan (paired sample $t$ test) menyatakan bahwa ada perbedaan SHU sebelum menerima dana bergulir dengan sesudah menerima dana bergulir pada tahun pertama (2010) yang artinya dana bergulir berpengaruh terhadap pengembangan SHU koperasi simpan pinjam agribisnis di Kabupaten Majalengka.
Pada tahun kedua (2011) setelah menerima dana bergulir SHU koperasi mengalami kenaikan sebesar $-27.61 \%$. Hasil perhitungan menggunakan rumus uji $t$ berpasangan (paired sample $t$ test) menyatakan bahwa tidak ada perbedaan SHU sebelum menerima dana bergulir dengan sesudah menerima dana bergulir pada tahun kedua (2011).

Berdasarkan laporan keuangan, koperasi yang mengalami penurunan SHU pada tahun kedua (2011) yaitu Koperasi Karya Mukti dan Koperasi Babussalam. Penurunan SHU dikarenakan pada tahun 2011 pengembalian pinjaman/pembiayaan dari anggota mengalami kemacetan sedangkan beban biaya usaha yang dikeluarkan semakin besar.

5. Pengaruh Penyaluran Dana Bergulir Terhadap Pengembangan Tenaga Kerja

Pada tahun pertama (2010) setelah menerima dana bergulir jumlah tenaga kerja koperasi mengalami kenaikan sebesar 29.41\%. Hasil perhitungan menggunakan rumus uji $\mathrm{t}$ berpasangan (paired sample $\mathrm{t}$ test) menyatakan bahwa ada perbedaan jumlah tenaga kerja sebelum menerima dana bergulir dengan sesudah menerima dana bergulir pada tahun pertama (2010) yang artinya dana bergulir berpengaruh terhadap pengembangan tenaga kerja koperasi simpan pinjam agribisnis di Kabupaten Majalengka.

Pada tahun kedua (2011) setelah menerima dana bergulir jumlah tenaga kerja koperasi mengalami kenaikan sebesar $48.53 \%$. Hasil 
perhitungan menggunakan rumus uji $t$ berpasangan (paired sample $t$ test) menyatakan bahwa ada perbedaan jumlah tenaga kerja sebelum menerima dana bergulir dengan sesudah menerima dana bergulir pada tahun kedua (2011) yang artinya dana bergulir berpengaruh terhadap pengembangan jumlah tenaga kerja koperasi simpan pinjam agribisnis di Kabupaten Majalengka.

Hal ini dapat dilihat di lapangan koperasi menambah jumlah tenaga kerja untuk meningkatkan pelayanan, penambahan kerja biasanya pada Teller dan Collector karena meningkatkannya jumlah anggota dan jumlah pemberian pinjaman.

\section{KESIMPULAN DAN SARAN}

\section{Kesimpulan}

Berdasarkan hasil penelitian yang dilakukan di LPDB-KUMKM dan koperasi simpan pinjam agribisnis di Kabupaten Majalengka diperoleh kesimpulan sebagai berikut :

1. Penyaluran dana bergulir LPDBKUMKM bagi Koperasi simpan pinjam dilakukan dengan sistem executing dimana ini koperasi simpan pinjam mempunyai tanggung jawab menyeleksi dan menetapkan penerima dana bergulir, menyalurkan dan menagih kembali dana bergulir, serta menanggung risiko terhadap ketidaktertagihan dana bergulir.
2. Berdasarkan penghitungan menggunakan rumus presentase pengembangan usaha diperoleh peningkatan nilai aset setelah menerima dana bergulir pada tahun pertama (2010) sebesar $28.06 \%$ dan pada tahun kedua (2011) sebesar 55.99\%. Peningkatan nilai pinjaman/pembiayaan setelah menerima dana bergulir pada tahun pertama (2010) sebesar $26.07 \%$ dan pada tahun kedua (2011) sebesar 54.94\%. Peningkatan nilai modal sendiri setelah menerima dana bergulir pada tahun pertama (2010) sebesar $13.33 \%$ dan pada tahun kedua (2011) sebesar 67.24\%. Peningkatan SHU setelah menerima dana bergulir pada tahun pertama (2010) sebesar $27.61 \%$ dan pada tahun kedua mengalami peningkatan sebesar 27.61\%. Peningkatan jumlah tenaga kerja setelah menerima dana bergulir pada tahun pertama (2010) sebesar $29.41 \%$ dan pada tahun kedua (2011) sebesar 48.53\%.

3. Berdasarkan hasil analisis menggunakan paired sample $t$ test dana bergulir berpengaruh terhadap pengembangan aset pada tahun kedua (2011), pemberian pinjaman/pembiayaan pada tahun pertama (2010), modal sendiri koperasi pada tahun kedua (2011), dan jumlah tenaga kerja koperasi pada tahun pertama (2010) dan tahun kedua (2011).

\section{Saran}

Berdasarkan pembahasan dari penelitian ini dapat disarankan beberapa hal, yaitu sebagai berikut: 
1. Kepada LPDB-KUMKM disarankan dalam penyaluran dana bergulir diharapkan tepat waktu dan tepat jumlah sesuai kondisi koperasi.

2. Kepada Koperasi simpan pinjam agribisnis disarankan agar lebih kooperatif serta semangat dalam pengelolaan dan pengembangan usaha koperasi.

3. Perlu penelitian lanjutan untuk mengetahui efektifitas penyaluran dana bergulir dari koperasi simpan pinjam bagi anggota UMKM agribisnis.

\section{DAFTAR PUSTAKA}

Anoraga, Pandji \& Ninik Widiyanti. 2007. Dinamika Koperasi. Cet. V. Penerbit PT. Rineka Cipta, Jakarta.

Ashari. 2009. Optimalisasi Kebijakan Kredit Program Sektor Pertanian Di Indonesia. Analisis Kebijakan Pertanian. Volume 7.

Batavia Online. Koperasi Sumbang PDB $56,2 \% \quad 12 \quad$ Juli 2010. http://bataviase.co.id/node/291047. 18 November 2011, pk. 20:30 WIB

Burhanuddin. 2006. Evaluasi Program Bantuan Dana Bergulir Melalui KSP/USP Koperasi (Pola PKPSBBM, Agribisnis dan Syariah). Jurnal Pengkajian Koperasi Dan UKM Nomor 1.
Dewan Koperasi Indonesia. 2002. Koperasi Untuk Pemberdayaan Usaha Kecil dan Menengah. Penerbit DEKOPIN dan Universitas Negeri Yogyakarta, Yogyakarta.

Iskandar. 2009. Metodologi Penelitian Dan Sosial: Kuantitatif dan Kualitatif. Cet. II. Penerbit Gaung Press Persada, Jakarta.

Keputusan Menteri Keuangan Nomor Kep292/MK.5/2006 Tentang Penetapan Lembaga Pengelola Dana Bergulir Koperasi dan Usaha Mikro Kecil Menengah Sebagai Instansi Pemerintah Yang Menerapkan Pola Pengelolaan Keuangan Badan Layanan Umum (PPK-BLU). http://danabergulir.com.

November 2011, pk. 19:10 WIB.

Komite Standar Akuntansi Pemerintahan. Buletin Teknis Standar Akuntansi

Pemerintah Nomor 7. 2 Juli 2011, pk. 15:20 WIB.

Lukman, Urhen. Kebijakan Program Bantuan Dana Bergulir Dalam Pengembangan KUMKM Nasional. : Temu Mitra Nasional di Batam 2011. Dokumen Lembaga Pengelola Dana Bergulir. 14 Desember 2011. 
McGraw \& Hill. Editor Alfonsus Sirait. 1987. Agribusiness Management. Penerbit Erlangga, Jakarta.

Panggabean, Riana. Efektivitas Program Dana Bergulir Bagi Koperasi dan UKM.

Dokumen Kementrian Koperasi dan Usaha Kecil dan Menengah.18 November 2011.

Panggabean, Riana. Pengembangan Usaha Simpan Pinjam Salah Satu Strategi Membangun Sistem Keuangan Koperasi. Dokumen Kementrian Koperasi dan Usaha Kecil dan Menengah. 30 Desember 2011.

Patriatiningrum, Rahmawati. 2007. Analisis Penerapan PSAK No.27 Akuntansi Koperasi Dan Pengaruhnya Terhadap Perkembangan Usaha Pada KUD Di Kabupaten Kendal Tahun 2004-2005. Skripsi S-1 Fakultas Ekonomi Jurusan Akuntansi. Universitas Negeri Semarang.

Peraturan Direksi Lembaga Pengelola Dana Bergulir Koperasi Dan Usaha Mikro Kecil Dan Menengah Nomor 011/PER/LPDB/2011 Tentang Petunjuk Teknis Pemberian Pinjaman Kepada Usaha Kecil Dan Menengah.

Peraturan Menteri Negara Koperasi Dan Usaha Kecil Dan Menengah Nomor
06/Per/M.KUKM/V/2006 Tentang Pedoman Penilaian Koperasi Berprestasi /Koperasi Award.

Peraturan Menteri Negara Koperasi Dan Usaha Kecil Dan Menengah Nomor 22/PER/M.KUKM/IV/2007 Tentang Pedoman Pemeringkatan Koperasi.

Peraturan Menteri Negara Koperasi Dan Usaha Kecil Dan Menengah Nomor 05/Per/M.KUKM/VI/2011 Tentang Organisasi Dan Tata Kerja Lembaga Pengelola Dana Bergulir Koperasi, Usaha Mikro, Kecil, Dan Menengah.

Peraturan Pemerintah Nomor 9 Tahun 1992 Tentang Kegiatan Usaha Simpan Pinjam.

Priyatno, Duwi. 2008. Mandiri Belajar SPSS 2008. Penerbit PT Buku Kita, Yogyakarta.

Salinan Peraturan Menteri Keuangan No.99/PMK.05/2008 Tentang Pedoman Pengelolaan Dana Bergulir Pada Kementrian Negara/ Lembaga.

Sartika, Tiktik \& Abd Rachman. Editor Lolita Krisnawati. 2004. Ekonomi Skala Kecil/ Menengah Dan Koperasi. Cet.II. Penerbit Ghalia Indonesia, Bogor. 
Situs Pemerintah Kabupaten Majalengka. Potensi Pertanian KabupatenMajalengka.http://www.m ajalengkakab.go.id. 27 Desember 2011 pk. 18.00 WIB.

Soedjono, Ibnoe. et al. 2000. Pengantar Bungaran Saragih. Membangun Koperasi Pertanian Berbasis Anggota. Penerbit LSP21, Jakarta.

Soekartawi. 1999. Agribisnis Teori Dan Aplikasinya. Ed. 1. Cet. V. PT Raja Grafindo Persada, Jakarta.

Sri \& Edi Swasono (Ed.). Koperasi Di Dalam Orde Ekonomi Indonesia : Mencari Bentuk, Posisi, Dan Realitas. Cet. III. Penerbit Universitas Indonesia (UI Press), Jakarta.

Suara Majalengka Online . Banyak Koperasi Sudah Tidak Aktif 18 Agustus

2011.http://suaramajalengka.blogspot .com. 4 Januari 2011, pk. 17:15 WIB. Sugiyono. 2009. Stastika Untuk Penelitian. Cet. V. Penerbit Alfabeta, Bandung.
Sutrisno, Noer. Pasang Surut Perkembangan Koperasi Di Dunia dan Indonesia. Dokumen Kementrian Koperasi dan Usaha Kecil dan Menengah. 16 November 2011

Teguh, Muhammad. 2005. Metodologi Penelitian Ekonomi. Ed.1-3. Penerbit PT. Raja Grafindo Persada, Jakarta.

Undang-Undang RI Nomor 25 Tahun 1992 Tentang Perkoperasian. UndangUndang RI Nomor 10 Tahun 1998 Tentang Perbankan. Undang-Undang RI Nomor 13 Tahun 2003 Tentang Ketenagakerjaan.

Widiyanti, Ninik dan Sunindhia. 1989. Koperasi Dan Perekonomian Indonesia. Penerbit PT. Bina Aksara, Jakarta.

Wikipedia Bahasa Indonesia. Aset. http://id.wikipedia.org/wiki/Aset. 18 November 2011, pk. 18:00 WIB. 